Sains Malaysiana 46(7)(2017): 1033-1038

http://dx.doi.org/10.17576/jsm-2017-4607-04

\title{
Growth Conditions of Graphene Grown in Chemical Vapour Deposition (CVD)
}

(Keadaan Tumbesaran Grafin yang Dihasilkan dengan Pemendapan Wap Kimia)

\author{
MOHAMAd SHUKRI SiRAT, EdHUAN ISMAIL, HAdi PuRWANTO, MOHD ASYADI AZAM MOHD ABID \\ \& MOHD HANAFI ANI*
}

\begin{abstract}
The fabrication of high quality graphene has become the main interest in current chemical vapour deposition (CVD) method due to the scalability for mass production of graphene-based electronic devices. The quality of graphene is determined by defect density, number of layers and properties changed such as electron mobility, transparency and conductivity as compared to the pristine graphene. Here, we did a study on the effects of reaction conditions such as methane, $\mathrm{CH}_{4}$ concentration and deposition time towards the quality of graphene produced. We found that by lowering both $\mathrm{CH}_{4}$ concentration down to $20 \%$ and deposition time to $5 \mathrm{~min}$, a better quality graphene was produced with higher $I_{2 D} / I_{G}$ ratio of 0.82 compared to other reaction condition. Through the analysis, we concluded that there are two important parameters to be controlled to obtain high quality graphene.
\end{abstract}

Keywords: Chemical vapour deposition (CVD); graphene; optimization

ABSTRAK

Penghasilan grafin yang berkualiti tinggi menjadi tumpuan utama dalam kaedah pemendapan wap kimia (CVD) pada masa kini kerana ia boleh diskalakan untuk pengeluaran peranti elektronik berasaskan grafin secara besar-besaran. Kualiti grafin diukur daripada jumlah kecacatan, jumlah lapisan dan perubahan sifat lain seperti pergerakan elektron, ketelusan dan daya konduksi jika dibandingkan dengan grafin asli. Di sini, kami telah menjalankan kajian perubahan keadaan tindak balas seperti kepekatan metana, $\mathrm{CH}_{4}$ dan masa pemendapan terhadap kualiti grafin yang dihasilkan. Kami telah mengenal pasti dengan menurunkan kedua-dua kepekatan $\mathrm{CH}_{4}$ sehingga $20 \%$ dan masa pemendapan sehingga 5 min akan menghasilkan kualiti grafin yang lebih baik dengan nisbah $I_{2 D} / I_{G}$ sebanyak 0.82 lebih tinggi berbanding keadaan tindak balas lain. Menerusi analisis ini, kami menyimpulkan bahawa terdapat dua parameter penting yang perlu dikawal untuk menghasilkan grafin yang berkualiti tinggi.

Kata kunci: Grafin; pemendapan wap kimia (CVD); pengoptimuman

\section{INTRODUCTION}

Since its debut in 2004, graphene has become the main interest amongst research societies due to its superlative characteristics such as high electron mobility (Bolotin et al. 2008), transparency (Nair et al. 2008) and high strength (Lee et al. 2008) that will allow it to be used in many applications especially in the electronic industries. Therefore, mass production of high quality graphene is a must. In recent years, CVD have shown the capability to produce graphene in large scale with promising quality by using $\mathrm{Cu}$ as the catalyst or substrate to decompose hydrocarbon gas such as methane, $\mathrm{CH}_{4}$ (Chan et al. 2013; Faggio et al. 2013; Li et al. 2009)graphene is limited to small sizes because it is produced mostly by exfoliating graphite. We grew large-area graphene films of the order of centimeters on copper substrates by chemical vapour deposition using methane. The films are predominantly single-layer graphene, with a small percentage (less than $5 \%$. However, most of the graphene produced was multilayered with a polycrystalline structure that consists of many graphene domains which have been separated by grain boundaries thus degrading several of its properties (Huang et al. 2011; Song et al. 2012; Yazyev \&Louie 2010). The graphene domains are believed to form due to the morphology of polycrystalline $\mathrm{Cu}$ such as defects, surface roughness and grain boundaries that acted as nucleation sites (Han et al. 2011) and cause uneven growth of graphene during the deposition process. Thus, multiple graphene domains are formed at various orientations and in certain conditions could even overlap with other domains. As a result, multilayer graphene with a polycrystalline structure is produced.

There are several approaches taken to tackle this problem. One of them is by removing surface imperfections through various pretreatments such as $\mathrm{Cu}$ electropolishing (Luo et al. 2011) and hydrogen, $\mathrm{H}_{2}$ annealing (Ibrahim et al. 2015; Jung et al. 2014) that causes graphene domain density and its overall thickness could be controlled. Apart from that, one group oversaw the approach of growing graphene epitaxially on $\mathrm{Cu}(111)$ and $\mathrm{Cu}(100)$ film to fabricate a single layer graphene (Hu et al. 2012) and it seems that there is a preferred surface orientation for single 
layer graphene to grow (Ishihara et al. 2011; Wood et al. 2011) thus showing that $\mathrm{Cu}$ crystal structure do have effect on the quality of graphene growth. Additionally, surface orientation of $\mathrm{Cu}$ might also affect the domain structures of the graphene produced (Ogawa et al. 2012). However, the influence of substrate's surface orientation towards the formation of high quality graphene is still not fully understood. Another approach taken was by controlling the reaction parameters such as temperature, pressure and the gas composition (Yang et al.2014) in order to produce a better graphene quality. Despite of all these efforts to improve the quality of graphene, the real understanding towards graphene growth mechanism is not yet fully understood.

Nucleation of new phases exists when supersaturation of solute in solution occurs thus inducing an increase in Gibbs free energy. In order to reduce the energy of the system, the solute will segregate from the solution forming other phases that are stable. Classical theory of deposition cited that Gibbs volume free energy for nucleation are as follows (Sree Harsha 2006):

$$
\Delta G_{v}=\frac{-k T}{\Omega} \ln \frac{C}{C_{0}}=\frac{-k T}{\Omega} \ln (1+\sigma)
$$

where is Gibbs volume free energy; is the atomic volume; $C$ is the concentration of solute; $C_{0}$ is the equilibrium concentration; and is the supersaturation defined as (C$\left.\mathrm{C}_{0}\right) / \mathrm{C}_{0}$. As the increases, the supersaturation of solute happens thus initiating segregation, which will reduce the Gibbs free energy.

Nucleation density is basically caused by the rate of deposition of the solute species, which is carbon in this case. The higher the rate of carbon deposition, the higher the nucleation density, thereby, would produce a fine grain polycrystalline graphene. The rate of deposition is controlled by the amount of carbon species supplied during the deposition process. Therefore, by understanding the nucleation and growth theory, this research intends to develop the optimized condition for graphene growth by manipulating the reaction condition especially methane $\left(\mathrm{CH}_{4}\right)$ gas concentration and deposition time to produce better graphene.

\section{METHODS}

\section{SAMPLE PREPARATION}

Commercially available polycrystalline $\mathrm{Cu}$ was used with foil thickness of $0.15 \mathrm{~mm}$. They were cut into 10 by $10 \mathrm{~mm}$, polished by using 1 micron alumina polish and ultrasonically cleaned with distilled water for $5 \mathrm{~min}$.

\section{GRAPHENE GROWTH}

The furnace setup is shown in Figure 1 where three types of gases involved in the graphene growth process are Ar, $\mathrm{H}_{2}$ and $\mathrm{CH}_{4}$.

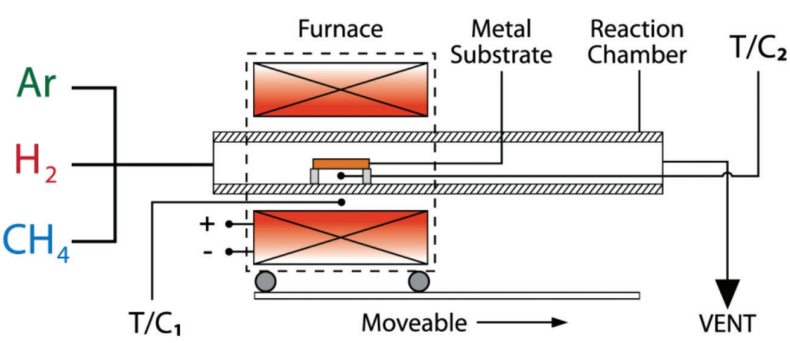

FIGURE 1. Furnace setup for graphene growth process

First, the sample was loaded into a $15 \mathrm{~mm}$ diameter quartz reactor as shown in Figure 1. The reactor was purged by using Ar gas to make sure that air inside the reactor was removed. The total flow rate used during the process is 50 sccm at ambient pressure and was kept constant throughout the experiment.

Annealing process started when the temperature reached $1000^{\circ} \mathrm{C}$ for $30 \mathrm{~min}$ with the introduction of $20 \%$ $\mathrm{H}_{2}$ in Ar gas.

Subsequently, the graphene growth was initiated by the introduction of $\mathrm{CH}_{4}$ gas in the presence of $\mathrm{Ar} 20 \% \mathrm{H}_{2}$ gas according to the reaction time and $\mathrm{CH}_{4}$ concentration shown in Table 1 . The reaction temperature remained at a constant $1000^{\circ} \mathrm{C}$ throughout the whole experiment.

After that, the furnace was moved from the reaction place for accelerated cooling under a flow of $\mathrm{Ar} 20 \% \mathrm{H}_{2}$ with the cooling rate of $\sim 113^{\circ} \mathrm{C} \mathrm{min}^{-1}$. Then, $\mathrm{H}_{2}$ gas supply was shut off and $100 \%$ Ar was kept flowing for 15 min to make sure that all $\mathrm{H}_{2}$ gas was completely removed from the furnace.

TABLE 1. Reaction time and $\mathrm{CH}_{4}$ concentration used during graphene growth process at $1000^{\circ} \mathrm{C}$

\begin{tabular}{|c|c|}
\hline Reaction time (min) & Concentration $(\%)$ \\
\hline 5 & $\begin{array}{l}20 \\
60\end{array}$ \\
\hline 15 & $\begin{array}{l}20 \\
60\end{array}$ \\
\hline 30 & $\begin{array}{l}20 \\
60\end{array}$ \\
\hline
\end{tabular}

\section{CHARACTERIZATION}

The morphology of graphene was studied using optical microscope (OLYMPUS BX-41-M) and the quality of graphene produced was indicated by using Raman spectroscopy machine (UniRAM 3500) with a wavelength of $532 \mathrm{~nm}$ and wave number ranging from 0 to $4000 \mathrm{~cm}^{-1}$. The Raman spectroscopy was conducted directly onto $\mathrm{Cu}$ substrates without performing any graphene transfer process. Despite the fluorescence effects of $\mathrm{Cu}$, it has been reported that the graphene spectra on $\mathrm{Cu}$ is still reliable enough (Costa et al. 2012). 


\section{RESULTS AND DISCUSSION}

\section{OPTICAL MICROSCOPY (OM)}

Figure 2 shows the OM images taken after graphene deposition process was done at respective reaction time and $\mathrm{CH}_{4}$ concentration. By observing these images, it could be seen that there were very large $\mathrm{Cu}$ grain boundaries (highlighted with dotted lines) with differing color contrasts. Additionally, near perfect parallel striations could be noticed within each grain boundaries but at various orientations as shown by the arrows in Figure 2 . Later, Raman analysis proved that this deposited striations to be graphene. First of all, the different orientations of these striations indicated different surface orientation for the deposited graphene. It could be safely concluded that this is due to the polycrystalline nature of the $\mathrm{Cu}$ substrates where the differing orientation of $\mathrm{Cu}$ grain was influencing the deposited graphene. Next, the color contrast of the striation within each grain is also worth noting. The bands of light and dark contrast in each grain were believed to originate from the differing thickness of the deposited graphene (Borah et al. 2015). However, this disparity in contrast gradually disappeared with increasing $\mathrm{CH}_{4}$ concentration which suggests an improvement in homogeneity of the graphene deposit. Besides, it seems that there is a preferred direction for graphene to grow in each $\mathrm{Cu}$ grains, which was limited by the grain boundaries at any reaction condition and shows that the growth of the graphene started at the grain boundaries of $\mathrm{Cu}$.

Figure 3 shows the graph of $\mathrm{Cu}$ grain density over reaction time at respective $\mathrm{CH}_{4}$ concentration. From this figure, it can be seen that the grain density decreases for both $\mathrm{CH}_{4}$ concentration as the deposition time increases, showing that longer reaction time could produce lower $\mathrm{Cu}$ grain density. This could be understood as longer reaction time yields larger $\mathrm{Cu}$ grain size since the reaction temperature at $1000^{\circ} \mathrm{C}$ is sufficiently high enough to promote the growth of $\mathrm{Cu}$ crystals thus producing lower grain density (Ago et al. 2015; Borah et al. 2015). Since
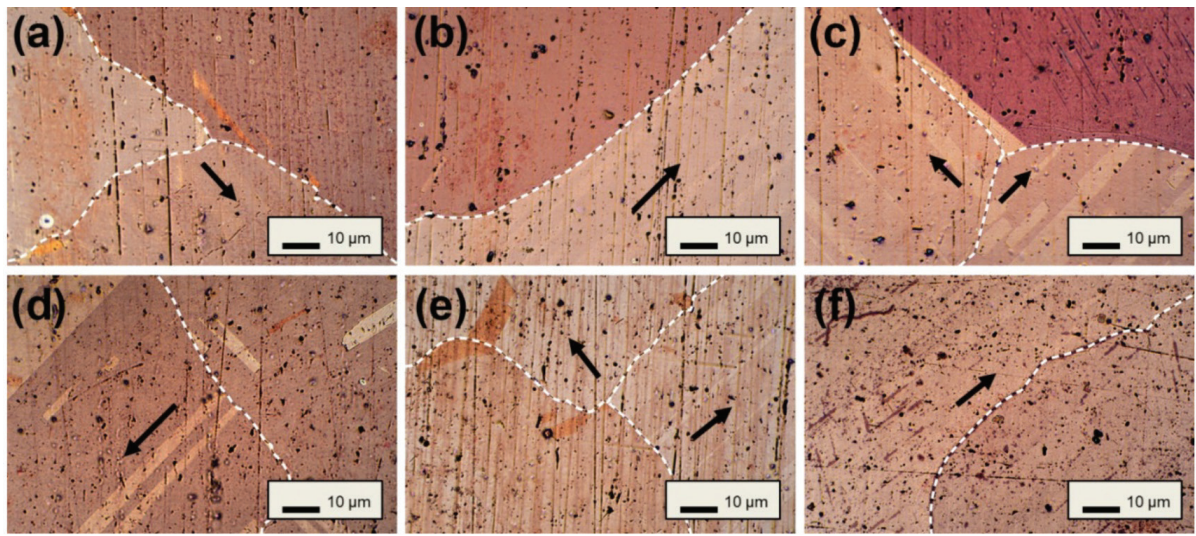

FIGURE 2. OM images of as-grown graphene on top of $\mathrm{Cu}$ substrates, (a) $5 \mathrm{~min}, 20 \% \mathrm{CH}_{4}$ (b) $15 \mathrm{~min}$, $20 \% \mathrm{CH}_{4}$ (c) $30 \mathrm{~min}, 20 \% \mathrm{CH}_{4}$ (d) $5 \mathrm{~min}, 60 \% \mathrm{CH}_{4}$ (e) $15 \mathrm{~min}, 60 \% \mathrm{CH}_{4}$ and (f) $30 \mathrm{~min}, 60 \% \mathrm{CH}_{4}$

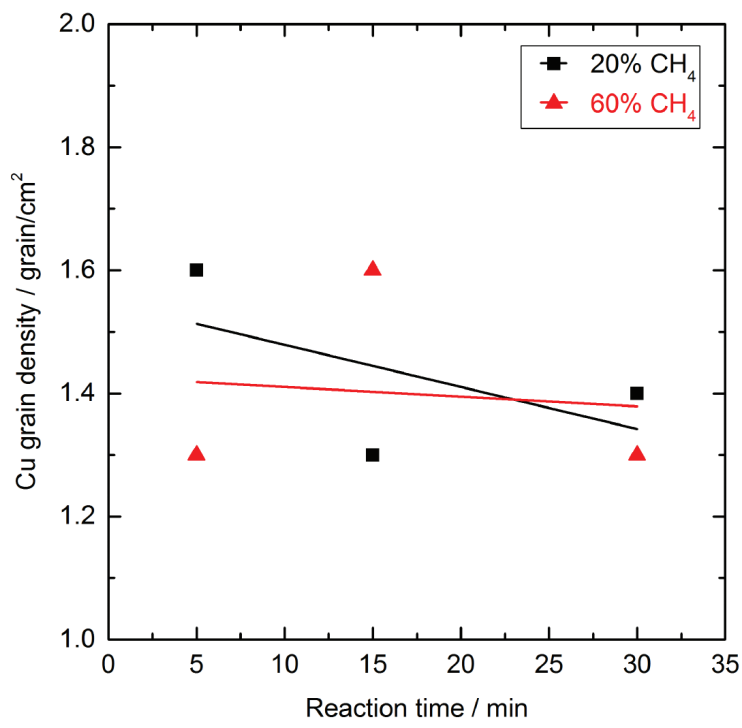

FIGURE 3. Change of $\mathrm{Cu}$ grain size against reaction time 
lower grain density is desirable for high quality graphene growth, future works will attempt to optimize the pretreatment annealing procedure based on this data.

\section{RAMAN SPECTROSCOPY}

All Raman test was done directly on the deposited graphene without doing any transfer process. Based on the result shown in Figure 4, it can be seen that all deposited carbon showed the graphitic peak such as D-band, G-band and 2D-band (Malard et al. 2009) which shows that all of them are graphene.

The existence of D-band determines the amount of defect presence in the deposited graphene. All of them appear at $\sim 1390 \mathrm{~cm}^{-1}$ shifted about $40 \mathrm{~cm}^{-1}$ from the theoretical graphene peak of $1350 \mathrm{~cm}^{-1}$ (Childres et al.2013). This can be explained due to existence of large amount of defects on the graphene produced such as grain boundaries (Yu et al. 2011). Besides that, there is another defect peak known as D+G-band appearing at $\sim 2920 \mathrm{~cm}^{-1}$. This peak emerged due to large defects contained in the deposited graphene (Dresselhaus et al. 2010). In Figure 4(a), we can see that at $20 \% \mathrm{CH}_{4}$ concentration, there is no significant change in D-band intensity indicating that all of the deposited graphene contained approximately the same amount of defects as the deposition time increased. Only when the concentration was changed to $60 \% \mathrm{CH}_{4}$, fluctuation of D-band intensity appeared, showing that they have inconsistent amount of defects as shown in Figure 4(b).

2D-band represents the graphene layer thickness by analyzing the peak's shape and calculating its full-width half maximum (FWHM) and it only appears at certain graphene thickness. Typical graphene has FWHM of about 24 $\mathrm{cm}^{-1}$ (Malard et al. 2009) and any FWHM broader than that represents multilayer graphene. $2 \mathrm{D}$ peak with the highest intensity was obtained at $20 \% \mathrm{CH}_{4}$ and 5 min reaction time with a FWHM of $\sim 86 \mathrm{~cm}^{-1}$. Other conditions yield a very broad $2 \mathrm{D}$ peak which suggests a short reaction time and low $\mathrm{CH}_{4}$ concentration is desirable for the formation of monolayer graphene.

The other way to identify the amount of layers in graphene can be done through the calculation of $\mathrm{I}_{2 \mathrm{D}} / \mathrm{I}_{\mathrm{G}}$ ratio as decrease in layers would give higher ratio (Childres et al. 2013). Analyzing the peak ratios in Figure 4, it can be seen from Figure 5 that $\mathrm{I}_{2 \mathrm{D}} / \mathrm{I}_{\mathrm{G}}$ ratio is getting smaller as the deposition time increases for both $20 \%$ and $60 \%$ indicating increment in graphene layers. Lower $\mathrm{CH}_{4}$ concentration seems to have higher $\mathrm{I}_{2 \mathrm{D}} / \mathrm{I}_{\mathrm{G}}$ ratio and the highest ratio calculated is 0.82 for the $5 \mathrm{~min}$ reaction. This shows a short reaction time and low $\mathrm{CH}_{4}$ concentration is the optimal condition for monolayer graphene growth and this complies with the report that lower $\mathrm{CH}_{4}$ concentration reduces the nucleation density of graphene and forming a uniform layer of graphene (Liu et al . 2011)but also substantially influenced by the quality of $\mathrm{Cu}$ substrate and how the $\mathrm{Cu}$ substrate is pretreated. It is found that the micro-topography of the $\mathrm{Cu}$ surface strongly affects the uniformity of grown graphene while the purity of the $\mathrm{Cu}$ film determines the number of synthesized graphene layers at low pressure conditions. On the other hand, a minimum partial pressure of hydrocarbon is required for graphene to cover the $\mathrm{Cu}$ surface during graphene growth. The optimized bilayer graphene exhibits a maximum hole (electron. In our study, the reduction in $\mathrm{CH}_{4}$ concentration is expected to have the same effect.

Based on the Raman results discussed, it can be identified that the graphene produced is still multilayered and in defective form. However, it is understood that the quality of graphene can be controlled by manipulating the $\mathrm{CH}_{4}$ concentration and reaction time. This information is very useful and should become a benchmark for the next optimization process to fabricate a high quality graphene. (a)

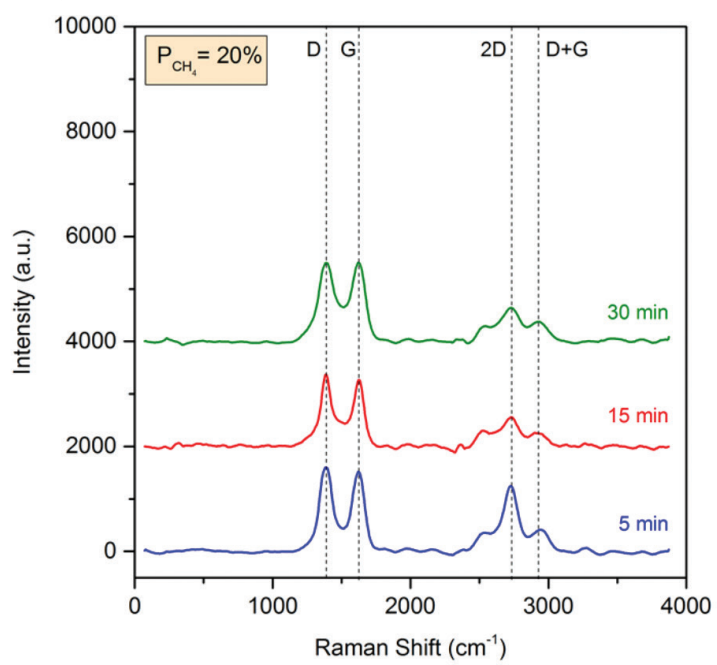

(b)

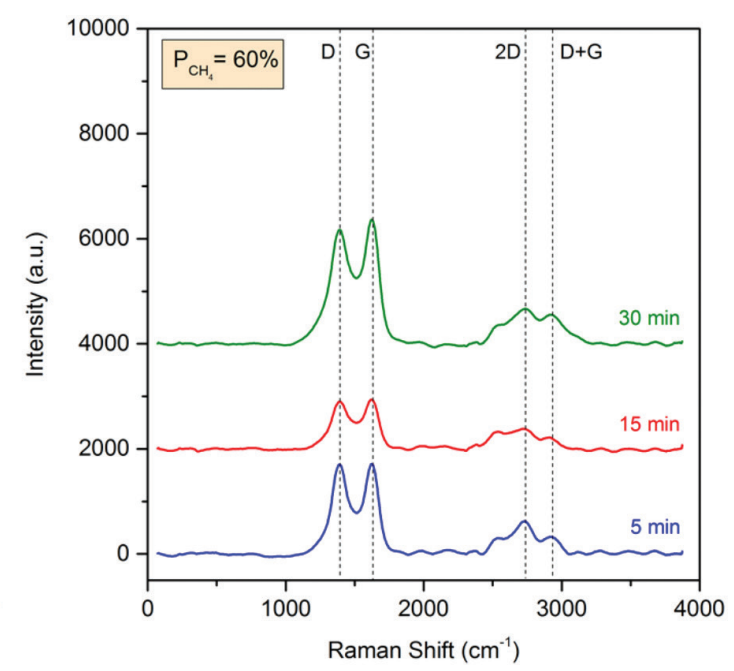

FIGURE 4. Raman spectroscopy of graphene on $\mathrm{Cu}$ (a) with $20 \% \mathrm{CH}_{4}$ (b) with $60 \% \mathrm{CH}_{4}$ during deposition process 


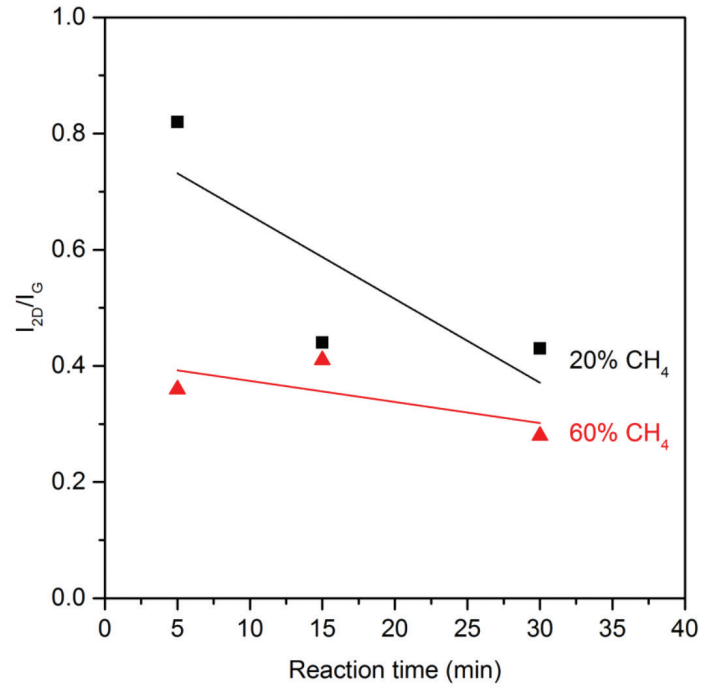

FIGURE 5. Change of $\mathrm{I}_{2 \mathrm{D}} / \mathrm{I}_{\mathrm{G}}$ ratio against reaction time

\section{CONCLUSION}

In order to summarize, graphene has been successfully fabricated by using ambient pressure CVD. The graphene produced has inconsistent number of graphene layers within each $\mathrm{Cu}$ grains as the color contrast of the striations observed from the OM images seems to suggest. When higher $\mathrm{CH}_{4}$ concentration was used, there was a marked reduction in the color contrast assuming a more homogeneous deposition. This is affirmed by Raman spectra as well which shows an overall improvement in the quality of the deposited graphene. Besides that, from the striations there are preferred directions for graphene to grow in each $\mathrm{Cu}$ grains which then limited by the $\mathrm{Cu}$ grain boundaries. The $\mathrm{Cu}$ grain density per $\mathrm{cm}^{2}$ was also calculated and it shows that higher reaction time will produce lower grain density. From the Raman, it can be identified that the graphene produced is highly defective as there is an existence of D-band which shifted about 40 $\mathrm{cm}^{-1}$ higher from the theoretical peak and the appearance of $\mathrm{D}+\mathrm{G}$ band at $\sim 2920 \mathrm{~cm}^{-1}$. FWHM of 2D band for all samples exceeds $24 \mathrm{~cm}^{-1}$ which shows that graphene produced is multilayered. From the $\mathrm{I}_{2 \mathrm{D}} / \mathrm{I}_{\mathrm{G}}$ plot, lower $\mathrm{CH}_{4}$ concentration of $20 \%$ and deposition time of 5 min yields the thinnest layer of graphene from all the samples obtained. Although the quality of the graphene produced is low but the pattern for optimization process has now been understood. Better quality graphene could be produced by decreasing the $\mathrm{CH}_{4}$ concentration and deposition time. This finding is expected will be useful to improve the quality of graphene production in the future.

\section{REFERENCES}

Ago, H., Ohta, Y., Hibino, H., Yoshimura, D., Takizawa, R., Uchida, Y., Tsuji, M., Okajima, T., Mitani, H. \& Mizuno, S. 2015. Growth dynamics of single-layer graphene on epitaxial $\mathrm{Cu}$ surfaces. Chemistry of Materials 27(15): 5377-5385. doi:10.1021/acs.chemmater.5b01871.
Bolotin, K.I., Sikes, K.J., Jiang, Z., Klima, M., Fudenberg, G., Hone, J., Kim, P. \& Stormer, H.L. 2008. Ultrahigh electron mobility in suspended graphene. Solid State Communications 146(9-10): 351-355. doi:10.1016/j.ssc.2008.02.024.

Borah, M., Singh, D.K., Subhedar, K.M. \& Dhakate, S.R. 2015. Role of substrate purity and its crystallographic orientation in the defect density of chemical vapour deposition grown monolayer graphene. RSC Adv. 5(85): 69110-69118. doi:10.1039/C5RA13480C.

Chan, S-H., Chen, S-H., Lin, W-T., Li, M-C., Lin, Y-C. \& Kuo, C-C. 2013. Low-temperature synthesis of graphene on $\mathrm{Cu}$ using plasma-assisted thermal chemical vapour deposition. Nanoscale Research Letters 8(1): 285. doi:10.1186/1556276X-8-285.

Childres, I., Jauregui, L., Park, W., Cao, H. \& Chen, Y.P. 2013. Raman spectroscopy of graphene and related materials. New Developments in Photon and Materials Research, edited by Jang, J.I. New York: Nova Science Publishers. doi:10.1016/ B978-0-444-53175-9.00016-7.

Costa, S.D., Righi, A., Fantini, C., Hao, Y., Magnuson, C., Colombo, L., Ruoff, R.S. \& Pimenta, M.A. 2012. Resonant Raman spectroscopy of graphene grown on copper substrates. Solid State Communications 152(15): 1317-1320. doi:10.1016/j.ssc.2012.05.001.

Dresselhaus, M.S., Jorio, A., Hofmann, M., Dresselhaus, G. \& Saito, R. 2010. Perspectives on carbon nanotubes and graphene Raman spectroscopy. Nano Letters 10(3): 751-758. doi:10.1021/n1904286r.

Faggio, G., Capasso, A., Messina, G., Santangelo, S., Dikonimos, Th., Gagliardi, S., Giorgi, R., Morandi, V., Ortolani, L. \& Lisi, N. 2013. High-temperature growth of graphene films on copper foils by ethanol chemical vapour deposition. The Journal of Physical Chemistry C 117(41): 21569-21576. doi:10.1021/jp407013y.

Han, G.H., Güneş, F., Bae, J.J., Kim, E.S., Chae, S.J., Shin, H.J., Choi, J.Y., Didier Pribat \& Lee, Y.H. 2011. Influence of copper morphology in forming nucleation seeds for graphene growth. Nano Letters 11(10): 4144-4148. doi:10.1021/ nl201980p.

Hu, B., Ago, H., Ito, Y., Kawahara, K., Tsuji, M., Magome, E., Sumitani, K., Mizuta, N., Ikeda, K.I. \& Mizuno, S. 2012. Epitaxial growth of large-area single-layer graphene over $\mathrm{Cu}\left(\begin{array}{lll}1 & 1 & 1\end{array}\right)$ /sapphire by atmospheric pressure CVD. Carbon 50(1): 57-65. doi:10.1016/j.carbon.2011.08.002.

Huang, P.Y., Ruiz-Vargas, C.S., van der Zande, A.M., Whitney, W.S., Levendorf, M.P., Kevek, J.W., Garg, S., Alden, J.S., Hustedt, C.J., Zhu, Y., Park, J., McEuen, P.L. \& Muller, D.A. 2011. Grains and grain boundaries in single-layer graphene atomic patchwork quilts. Nature 469(7330): 389-392. doi:10.1038/nature09718.

Ibrahim, A., Akhtar, S., Atieh, M., Karnik, R. \& Laoui, T. 2015. Effects of annealing on copper substrate surface morphology and graphene growth by chemical vapour deposition. Carbon 94: 369-377. doi:10.1016/j.carbon.2015.06.067.

Ishihara, M., Koga, Y., Kim, J., Tsugawa, K. \& Hasegawa, M. 2011. Direct evidence of advantage of $\mathrm{Cu}(111)$ for graphene synthesis by using Raman mapping and electron backscatter diffraction. Materials Letters 65(19-20): 2864-2867. doi:10.1016/j.matlet.2011.06.047.

Jung, D.H., Kang, C., Kim, M., Cheong, H., Lee, H. \& Lee, J.S. 2014. Effects of hydrogen partial pressure in the annealing process on graphene growth. The Journal of Physical Chemistry C 118(7): 3574-3580. doi:10.1021/jp410961m. 
Lee, C., Wei, X., Kysar, J.W. \& Hone, J. 2008. Measurement of the elastic properties and intrinsic strength of monolayer graphene. Science 321(5887): 385-388. doi:10.1126/ science.1157996.

Li, X., Cai, W., An, J., Kim, S., Nah, J., Yang, D., Piner, R., Velamakanni, A., Jung, I., Tutuc, E., Banerjee, S.K., Colombo, L. \& Ruoff, R.S. 2009. Large-area synthesis of high-quality and uniform graphene films on copper foils. Science 324(5932): 1312-1314. doi:10.1126/science.1171245.

Liu, W., Li, H., Xu, C., Khatami, Y. \& Banerjee, K. 2011. Synthesis of high-quality monolayer and bilayer graphene on copper using chemical vapour deposition. Carbon 49(13): 4122-4130. doi:10.1016/j.carbon.2011.05.047.

Luo, Z., Lu, Y., Singer, D.W., Berck, M.E., Somers, L.A., Goldsmith, B.R. \& Johnson, A.T.C. 2011. Effect of substrate roughness and feedstock concentration on growth of waferscale graphene at atmospheric pressure. Chemistry of Materials 23(6): 1441-1447. doi:10.1021/cm1028854.

Malard, L.M., Pimenta, M.A., Dresselhaus, G. \& Dresselhaus, M.S. 2009. Raman spectroscopy in graphene. Physics Reports 473(5-6): 51-87. doi:10.1016/j.physrep.2009.02.003.

Nair, R.R., Blake, P., Grigorenko, A.N., Novoselov, K.S., Booth, T.J., Stauber, T., Peres, N.M.R. \& Geim, A.K. 2008. Fine structure constant defines visual transperency of graphene. Science 320: 1308. doi:10.1126/science.1156965.

Ogawa, Y., Hu, B., Orofeo, C.M., Tsuji, M., Ikeda, K.I., Mizuno, S., Hibino, H. \& Ago, H. 2012. Domain structure and boundary in single-layer graphene grown on $\mathrm{Cu}(111)$ and $\mathrm{Cu}(100)$ films. Journal of Physical Chemistry Letters 3(2): 219-226. doi:10.1021/jz2015555.

Song, H.S., Li, S.L., Miyazaki, H., Sato, S., Hayashi, K., Yamada, A., Yokoyama, N. \& Tsukagoshi, K. 2012. Origin of the relatively low transport mobility of graphene grown through chemical vapour deposition. Sci. Rep. 2: 337. doi:10.1038/ srep00337.

Sree Harsha, K.S. 2006. Principles of Vapor Deposition of Thin Films. New York: Elsevier. doi:10.1016/B978-0080446998/50012-7.
Wood, J.D., Schmucker, S.W., Lyons, A.S., Pop, E. \& Lyding, J.W. 2011. Effects of polycrystalline $\mathrm{Cu}$ substrate on graphene growth by chemical vapour deposition. Nano Letters 11(11): 4547-4554. doi:10.1021/n1201566c.

Yang, H., Shen, C-M., Tian, Y., Wang, G-Q., Lin, S-X., Zhang, Y., Gu, C-Z., Li, J-J. \& Gao, H-J. 2014. Influence of reaction parameters on synthesis of high-quality single-layer graphene on $\mathrm{Cu}$ using chemical vapour deposition. Chinese Physics $B$ 23(9): 96803. doi:10.1088/1674-1056/23/9/096803.

Yazyev, O.V. \& Louie, S.G. 2010. Electronic transport in polycrystalline graphene. Nature Materials 9(10): 806-809. doi:10.1038/nmat2830.

Yu, Q., Jauregui, L.A., Wu, W., Colby, R., Tian, J., Su, Z., Cao, H., Liu, Z., Pandey, D., Wei, D., Chung, T.F., Peng, P., Guisinger, N.P., Stach, E.A., Bao, J., Pei, S.S. \& Chen, Y.P. 2011. Control and characterization of individual grains and grain boundaries in graphene grown by chemical vapour deposition. Nature Materials 10(6): 443-449. doi:10.1038/nmat3010.

Mohamad Shukri Sirat, Edhuan Ismail, Hadi Purwanto \& Mohd Hanafi Ani

Department of Manufacturing and Materials Engineering International Islamic University Malaysia (IIUM), Jalan Gombak 53100 Kuala Lumpur, Federal Territory

Malaysia

Mohd Asyadi Azam Mohd Abid

Faculty of Manufacturing Engineering

Universiti Teknikal Malaysia Melaka, Hang Tuah Jaya

76100 Durian Tunggal, Melaka Bandaraya Bersejarah Malaysia

*Corresponding author: mhanafi@iium.edu.my

Received: 31 October 2016

Accepted: 3 January 2017 